JURNAL PENDIDIKAN TEKNOLOGI INFORMASI

\title{
MENINGKATKAN HASIL BELAJAR MATERI MENGIDENTIFIKASI HAK ANGGOTA KELUARGA MELALUI MODEL PEMBELAJARAN KOOPERATIF TIPE JIGSAW PADA SISWA KELAS III SDN 5 MENDAWAI SEIMESTER 1 Improving Material Learning Outcomes To Identify The Rights Of Family Members Through Cooperative Learning Models In Jigsaw Type In Grade III Students SDN 5 Mendawai Semester 1 \\ SDN 5 Mendawai, Katingan, Kalimantan Tengah, Indonesia
}

ARTIKEL INFO

Diterima

Dipublikasi

10 September 2019

\section{ABSTRAK}

Penelitian ini bertujuan untuk: (I) mengetahui aktivitas belajar siswa dalam pembelajaran khususnya materi mengidentifikasi hak anggota keluarga melalui model pembelajaran kooperatif tipe jigsaw pada siswa kelas III SDN 5 Mendawai Semester I. (2) untuk mengetahui apakah ada atau tidaknya hasil belajar siswa pada materi mengidentifikasi hak anggota keluarga melalui model pembelajaran kooperatif tipe jigsaw pada siswa kelas III SDN 5 Mendawai Semester I. Penelitian ini menggunakan metode Penelitian Tindakan Kelas.

Kata Kunci: Hasil Belajar Siswa, Materi Mengidentifikasi ak Anggota Keluarga, Model Pembelajaran Kooperatif Tipe Jigsaw

\section{ABSTRACT}

This study aims to: (I) find out the learning activities of students in learning, especially the material to identify the rights of family members through a type of jigsaw cooperative learning model in grade III students of SDN 5 Mendawai Semester I. (2) to find out whether or not there are student learning outcomes in the material identify the rights of family members through a type of jigsaw cooperative learning model for grade III students of SDN 5 Mendawai Semester I. This study uses the Classroom Action Research method.

Keywords: Student Learning Outcomes, Material Identifying ak Family Members, Jigsaw Type Cooperative Learning Model

*e-mail :

Orcid : 


\section{Jurnal Pendidikan Teknologi Informasi}

\section{PENDAHULUAN}

Belajar adalah suatu proses menimba ilmu. Dengan belajar seseorang akan mendapatkan ilmu baru. Dengan adanya ilmu yang dimiliki, seseorang akan mudah menyelesaikan suatu permasalahan, baik permasalahan dalam diri ataupun permasalahan yang terjadi di sekitar lingkungan. Oleh karenanya siswa harus mempunyai Hasil belajar yang tinggi.

Salah satu tanggung jawab guru dalam proses belajar pengajar adalah meningkatkan Hasil belajar siswa agar proses belajar berhasil dengan baik. Keberhasilan ini banyak tergantung pada usaha guru untuk membangkitkan Hasil belajar siswa, sebagaimana guru menggunakan berbagai cara, pendekatan dengan siswa dan metode untuk membangkitkan belajar siswa dalam meningkatkan Hasil belajarnya, karena Prestasi meningkat bukan hanya dambaan setiap siswa maupun orang tua murid, seorang guru pun memiliki harapan akan peningkatan Hasil belajar siswa yang dibinanya. Akan tetapi tidak banyak guru memiliki ilmu atau kemapuan tentang strategi peningkatan Hasil belajar siswa.

Selain metode ceramah yang $\mathrm{Di}$ pakai guru sangat tidak menarik siswa untuk belajar, kurangnya minat siswa dalam menuntut ilmu ini juga disebabkan oleh kurang sadarnya siswa akan pentingnya ilmu itu. Siswa tersebut tidak tahu untuk apa mereka belajar ke sekolah. Mereka datang ke sekolah dari pagi hingga siang hari hanya sebagai kegiatan yang mereka anggap sebagai rutinitas yang harus dilakukan karena mengikuti perintah orang tua.

Sehubungan dengan itu, peneliti hendak mencoba menerapkan metode Jigsaw, Melalui metode jigsaw kelas dibagi menjadi beberapa tim yang anggotanya terdiri dari 5 atau 6 siswa dengan karakteristik yang heterogen. Bahan akademik disajikan kepada siswa dalam bentuk teks; dan tiap siswa bertanggung jawab untuk mempelajari suatu bagian dari bahan akademik tersebut.

Hasil belajar merupakan tujuan akhir dilaksanakannya kegiatan pembelajaran di sekolah. Hasil belajar dapat ditingkatkan melalui usaha sadar yang dilakukan secara sistematis mengarah kepada perubahan yang positif yang kemudian disebut dengan proses belajar. Akhir dari proses belajar adalah perolehan suatu hasil belajar siswa. Hasil belajar siswa di kelas terkumpul dalam himpunan hasil belajar kelas. Semua hasil belajar tersebut merupakan hasil dari suatu interaksi tindak belajar dan tindak mengajar. Dari sisi guru, tindak mengajar di akhiri dengan proses evaluasi hasil belajar, sedangkan dari sisi siswa, hasil belajar merupakan berakhirnya penggal dan puncak proses belajar (Dimyati dan Mudjiono, 2009: $3)$.

Jika dikaji lebih mendalam, maka hasil belajar dapat tertuang dalam taksonomi Bloom, yakni dikelompokkan dalam tiga ranah (domain) yaitu domain kognitif atau kemampuan berpikir, domain afektif atau sikap, dan domain psikomotor atau keterampilan. Sehubungan dengan itu, Gagne (dalam Sudjana, 2010: 22) mengembangkan kemampuan hasil belajar menjadi lima macam antara lain: (I) hasil belajar intelektual merupakan hasil belajar terpenting dari sistem lingsikolastik; (2) strategi kognitif yaitu mengatur cara belajar dan berfikir seseorang dalam arti seluas-luasnya termaksuk kemampuan memecahkan masalah; (3) sikap dan nilai, berhubungan dengan arah intensitas emosional dimiliki seseorang sebagaimana disimpulkan dari kecenderungan bertingkah laku terhadap orang dan kejadian; (4) informasi verbal, pengetahuan dalam arti informasi dan fakta; dan (5) keterampilan motorik yaitu kecakapan yang berfungsi untuk lingkungan hidup serta memprestasikan konsep dan lambang. 


\section{Jurnal Pendidikan Teknologi Informasi}

Instructional conditions, didefinisikan sebagai factor yang mempengaruhi metode pembelajaran dalam meningkatkan hasil pembelajaran. variable ini berinteraksi dengan metode pembelajaran, dan pada dasarnya tidak dapat dimanipulasi oleh perancang pembelajaran. variable ini harus diterima apa adanya, tetapi menjadi bahan pijakan dalam penetapan metode pembelajaran. contohnya seperti motivasi, minat, tingkat social siswa, bakat siswa, tingkat ekonomi dan sebagainya. Meskipun tidak dapat dimanipulasi, pada saat tertentu ia dapat pula dimanipulasi, jika pada saat posisinya berubah menjadi metode pembelajaran. contoh: siswa akan giat belajar, sebelum tes harian dilakukan, jika ada motivasi kepada siswa "Anak - anak, minggu depan tes harian! Bagi anak - anak yang memperoleh nilai 100, maka akan dapat hadiah berupa ...". Ini berarti kondisi sebelumnya siswa kurang berminat terhadap pelajaran tersebut. Oleh karena itu, guru menggunakan cara - cara agar memperoleh hasil tes meningkat.

Metode ini dikembangkan oleh Elliot Aronson dan kawan-kawannya dari Universitas Texas dan kemudian di adaptasi oleh Slavin dan kawan-kawannya. Melalui metode jigsaw kelas dibagi menjadi beberapa tim yang anggotanya terdiri dari 5 atau 6 siswa dengan karakteristik yang heterogen. Bahan akademik disajikan kepada siswa dalam bentuk teks; dan tiap siswa bertanggung jawab untuk mempelajari suatu bagian dari bahan akademik tersebut. Dalam hal ini peneliti menggunakan metode jigsaw. Istilah metode berasal dari bahasa Yunani "Metodos". Kata ini terdiri dari dua suku kata yaitu "Metha" yang berarti melalui atau melewati dan "hodos" jalan atau cara. Jadi metode adalah suatu jalan yang dilalui untuk mencapai suatu tujuan. Pengertian Kata jigsaw berasal dari bahasa Inggris yang berarti "gergaji atau memotong". Dalam metode pembelajaran teknik jigsaw termasuk dalam jenis metode pembelajaran kooperatif.

Eksperimen ini terdiri dari membentuk kelompok pembelajaran (kelompok jigsaw) dimana tiap pembelajar tergantung kepada anggota kelompoknya untuk mendapatkan informasi yang diperlukan untuk lulus dalam ujian. Tanpa memandang ras, mereka digabungkan menjadi sebuah grup dan wajib berkerjasama diantara anggotanya agar mencapai sukses akademik. Ketika dibandingkan dengan kelas tradisional dimana pembelajar-pembelajar bersaing secara individu, pembelajar-pembelajar di dalam kelas.

\section{Mengidentifikasi hak anggota keluarga}

a. Hak Ayah

Dalam keluarga seorang ayah memiliki hak untuk di hormati dan di sayangi. Karena ayah sebagai kepala keluarga maka perintahnya harus di patuhi, tetapi apa bila salah satu anggota keluarga tidak sependapat dengan perintah ayah, kita bisa mengatakan kepada ayah dengan baik dan sopan.

Sebagai kepala keluarga ayah juga berhak membuat peraturan, tetapi sebaiknya peraturan yang dibuat bersama anggota keluarga yang lain. Jika peraturan telah ditetapkan maka seluruh anggota keluarga harus mematuhi peraturan tersebut.

Ayah juga berhak memberi izin dan memberikan hukuman. Misalnya ayah tidak mengizinkan anaknya bermain jauh-jauh maka anak tersebut harus mematuhi perintah ayahnya, jika anak tersebut melanggar peraturan yang dibuat bersama maka anak tersebut mendapat hukuman. Biasanya hukuman yang diberikan ayah bersifat mendidik, karena ayah yang baik tidak akan menghukum anaknya tanpa alasan.

Walaupun ayah adalah pemimpin, maka ayah tidak boleh berbuat semaunya. Apabila didalam keluarga mendapatkan suatu masalah maka harus di musyawarakan bersama keluarga terlebih dahulu. 


\section{Jurnal Pendidikan Teknologi Informasi}

b. Hak lbu

Hak ibu adalah dihormati dan di sayangi oleh anggota keluarga. Apabila ibu memberikan nasehat kepda anaknya, maka sebagai anak harus mendengarkan nasehat ibu. Jika seorang anak tidak sependapat dengan ibu, anak tersebut dapat mengatakan kepada ibunya dengan baik dan sopan dan jangan sampai membantah atau menyakiti hati ibu.

Ibu juga memiliki hak untuk mendapatkan nafkah dari ayah, tetapi dengan berkembangnya zaman selain ayah banyak ibu yang bekerja untuk memenuhi kebutuhan keluarga.

c. Hak Anak

Seperti ayah dan ibu, anak juga mempunyai hak. Hak anak yaitu disayangi oleh orang tuanya. Anak juga mempunyai hak untuk mendapatkan perhatian dari orang tuanya. Jadi, kalau orang tuamu tidak memperhatikanmu, kamu boleh protes. Katakan pendapatmu pada orang tuamu dengan baik dan sopan.

Anak pun juga mempunyai hak untuk dibimbing dan diberi nafkahdari orang tuanya. Sebagai orang tua harus memberi tahu kepada anaknya yang mana yang benar dan mana yang salah. Orang tua juga harus memenuhi kebutuhan hidup anaknya. Namun, kebutuhan itu harus sesuai dengan kemampuan orang tua. Sebagai anak tidak boleh meminta barang yang terlalu mahal bagi orang tua.

d. Perubahan Peran dalam Keluarga

Pada umumnya seorang ayah adalah kepala keluarga dan ibu sebagai ibu rumah tangga yang tugasnya mendidik dan membimbing anak. Tetapi,sekarang banyak perempuan Indonesia yang menjadi Insinyur, dokter, Hakim, Guru dll. Bahkan ada juga yang menjadi anggota TNI dan Porli.

Banyak perempuan Indonesia yang menduduki jabatan penting. Ada yang bekerja dikantor pemerintahan, diperusahaan swasta, bahkan ada juga perempuan yang membuka usaha sendiri. Ada pula yang menjadi menteri dalam kabinet. Misalnya, Presiden wanita yaitu ibu Megawati.

Proses belajar mengajar adalah proses komunikasi yang didalamnya terdapat berbagai kegiatan belajar, salah satunya adalah dengan penyampaian media pembelajaran oleh guru. Guru sebagai pendidik dan penyelenggara kegiatan pembelajaran di kelas harus dapat mengoptimalkan kegiatan belajar. Pembelajaran merupakan suatu upaya yang dilakukan dengan sengaja oleh pendidik untuk menyampaikan ilmu pengetahuan dan menciptakan sistem lingkungan belajar mengajar dengan berbagai media, sumber dan metode. Dimana dengan menggunakan media, sumber, dan metode pembelajaran dimaksudkan agar siswa dapat melakukan kegiatan belajar secara efektif dan efisien sehingga hasil belajarnya dapat optimal.

\section{METODOLOGI PENELITIAN}

Penelitian ini berawal dari masalah dalam pembelajaran PKn di kelas III SDN 5 Mendawai. Hasil yang diperoleh melalui pengamatan menjadi dasar perencanaan penelitian ini. Tindakan yang dilakukan adalah dengan penerapan metode Jigsaw untuk meningkatkan Hasil belajar PKn pada siswa kelas III SDN 5 Mendawai.

I. Siklus I

Pelaksanaan tindakan siklus I difokuskan untuk mengetahui Prestasi siswa dalam belajar PKn menggunakan metode Jigsaw dalam proses pembelajaran yang berlangsung.

\section{a. Perencanaan}

Pada tahap perencanaan tindakan peneliti membuat rencana pembelajaran tari PKn yang memuat tentang tujuan yang ingin dicapai, materi pelajaran tari yang akan disampaikan, metode yang akan digunakan, bahan ajar, alat, dan evaluasi.

b. Implementasi Tindakan

Pelaksanaan tindakan dalam penelitian ini didasarkan pada rencana yang telah disusun, yaitu menerapkan metode Jigsaw dalam proses pembelajaran dengan tujuan untuk 


\section{Jurnal Pendidikan Teknologi Informasi}

mengetahui seberapa tinggi Prestasi siswa dalam belajar PKn.

\section{c. Observasi}

Observasi yang dilakukan bertujuan untuk mengetahui keaktifan belajar siswa, baik dalam perilaku, Prestasi, penerimaan materi, suasana pembelajaran serta aktivitas siswa terhadap penerapan media pembelajaran dalam proses pembelajaran PKn. Pelaksanaan observasi dilakukan pada saat proses pembelajaran berlangsung.

d. Refleksi dan Evaluasi

Setelah melakukan kegiatan observasi selama proses pembelajaran, kemudian dilakukan refleksi untuk mengingat dan merenungkan kembali hasil tindakan yang sudah dilaksanakan. Refleksi bertujuan untuk memperoleh dasar dari upaya dalam perbaikan dari hasil pembelajaran selanjutnya. Adapun evaluasi dilakukan dengan tujuan untuk mengetahui sejauh mana kemampuan siswa dalam penguasaan materi pembelajaran PKn.

2. Siklus II

Pelaksanaan tindakan siklus II ini bertujuan untuk meningkatkan kemampuan serta Prestasi siswa dalam belajar PKn. Siklus ini dilaksanakan untuk mencermati aktivitas peserta didik dalam pembelajaran dan hasil kerja kelompok. Dalam kegiatan siklus II ini juga terdiri atas 4 tahapan yang sama seperti siklus I, yaitu perencanaan, implementasi, observasi, refleksi, dan evaluasi.

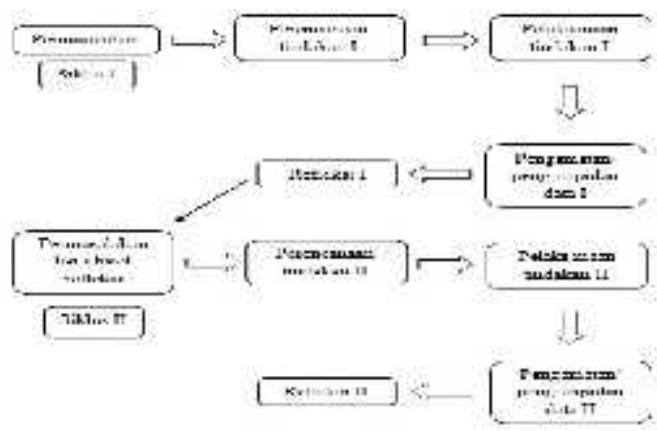

Gambar I: Bagan Model Penelitian Tindakan

Kelas (Kemmis dan Mc Taggart)

\section{HASIL DAN PEMBAHASAN}

Salah satu faktor penentu keberhasilan proses belajar mengajar di sekolah adalah kemampuan guru mengelola pembelajaran di kelas. Pengelolaan pembelajaran yang dimaksud adalah pengelolaan pembelajaran yang melibatkan guru dan siswa sebagai bagian dari proses pembelajaran tersebut. Artinya pembelajaran tidak harus selalu berpusat pada guru, tetapi juga melibatkan siswa sebagai objek yang paling berperan di dalamnya. Bila pembelajaran direncanakan dan dikelola dengan baik akan menciptakan proses belajar yang efektif bagi siswa dan guru.

Guru yang mengorganisasikan kelasnya dengan baik, yang memungkinkan berlangsungnya pembelajaran yang berstruktur, menghasilkan rasio keterlibatan siswa yang lebih tinggi, dan hasil belajar yang lebih tinggi dari pada guru yang menggunakan pendekatan kurang formal dan kurang terstruktur. Perencanaan dan pengelolaan yang baik oleh guru dapat membantu guru untuk lebih meprestasi siswa mengikuti pelajaran yang disajikan. Dengan terprestasinya siswa terhadap pembelajaran, berarti guru dapat lebih mengarahkan aktivitas siswa dalam pembelajaran. Perencanaan dan pengelolaan ini pun nantinya dapat menghasilkan hasil belajar yang lebih baik pula.

Salah satu perencanaan dan pengelolaan yang dimaksud adalah pembelajaran yang di desain dengan menggunakan metode belajar yang bervariasi. Salah satunya adalah dengan penggunaan metode Jigsaw. Setelah kegiatan diskusi berlangsung, sebagian siswa mempresentasikan hasil diskusi ke depan kelas dan guru memepersilakan siswa lain untuk mengomentarinya. Kegiatan pembelajaran berlangsung santai, menyenangkan, dan siswa merasa tidak tertekan. Guru dapat melihat antusias siswa selama KBM berlangsung. Tujuan pembelajaran tercapai dan hasilnya pun cukup baik. Desain belajar dengan menggunakan metode Jigsaw ini ternyata memberikan hasil 


\section{Jurnal Pendidikan Teknologi Informasi}

akhir pembelajaran yang cukup memuaskan. $\mathrm{Hal}$ ini diindikasikan dengan keterlibatan dan keaktifan siswa dalam mengikuti pembelajaran yang sebelumnya memiliki rasa kurang tertarik menjadi terprestasi untuk mengikutinya.

\section{KESIMPULAN}

Upaya untuk meningkatkan hasil belajar PKn melalui metode Jigsaw pada siswa kelas III SDN 5 Mendawai, dilaksanakan dalam dua tahap, yaitu siklus I dan siklus II sudah ada peningkatan dan memenuhi kriteria keberhasilan tindakan. Hal itu terlihat pada hasil hasil belajar PKn dilihat dari hasil observasi dan hasil rekapitulasi angket. Peningkatan secara proses dan hasil dapat dilihat berdasarkan skor rata-rata yang diperoleh pada siklus II dibandingkan dengan skor rata-rata yang diperoleh pada saat siklus I.

Persentase hasil belajar siswa pada pratindakan penelitian dengan kategori pengamatan: (I) mendengarkan/ memperhatikan penjelasan guru $37,5 \%$, (2) membaca buku siswa 57,5\%, (3) mengajukan pertanyaan $5 \%$, (4) menanggapi pertanyaan/pendapat guru $10 \%$, (5) menanggapi pertanyaan/pendapat siswa $2,5 \%$,

(6) bertukar pendapat dengan teman sekelompok 2,5\%, (7) menulis yang relevan dengan KBM 50\%, (8) menyatakan ide dengan jelas $12,5 \%$, (9) mendengarkan penjelasan siswa $10 \%$, dan (10) perilaku yang tidak relevan dengan KBM $20 \%$.

Adapun hasil persentase jumlah siswa yang mengikuti aktivitas belajar pada siklus I dengan kategori pengamatan: mendengarkan/memperhatikan penjelasan guru 50\%, (2) membaca buku siswa 50\%, (3) mengajukan pertanyaan $12,5 \%$, menanggapi pertanyaan/pendapat guru $17,5 \%$, (5) menanggapi pertanyaan/ pendapat siswa $10 \%$, (6) bertukar pendapat dengan teman sekelompok 15\%, (7) menulis yang relevan dengan KBM 40\%, (8) menyatakan ide dengan jelas $17,5 \%$, mendengarkan penjelasan siswa $22,5 \%$, dan (10) perilaku yang tidak relevan dengan KBM I5\%. Hal ini menunjukkan bahwa hasil belajar siswa mengikuti KBM sudah tinggi.

Hasil siklus II, ditunjukkan persentase jumlah siswa yang mengikuti aktivitas belajar dengan kategori pengamatan: mendengarkan/memperhatikan penjelasan guru $62,5 \%$, (2) membaca buku siswa 30\%, (3) mengajukan pertanyaan $25 \%$, (4) menanggapi pertanyaan/pendapat guru 25\%, (5) menanggapi pertanyaan/pendapat siswa $20 \%$, (6) bertukar pendapat dengan teman sekelompok 30\%, (7) menulis yang relevan dengan KBM $10 \%$, (8) menyatakan ide dengan jelas $35 \%$, (9) mendengarkan penjelasan siswa $32,5 \%$, dan (10) perilaku yang tidak relevan dengan KBM 10\%. Hal ini mengindikasikan bahwa hasil belajar siswa mengikuti KBM sudah baik.

Berdasarkan kesimpulan dan hasil penelitian di atas, saran untuk penelitian ini adalah sebagai berikut.

I. Bagi guru khususnya PKn disarankan untuk menggunakan metode Jigsaw dalam pembelajaran gar pembelajaran lebih efektif dan menyenangkan.

2. Bagi siswa, hasil belajar PKn ditingkatkan dan dipertahankan secara terus-menerus, kemudian diharapkan siswa dapat memanfaatkan sebaik mungkin kegiatan mengamati video.

\section{DAFTAR PUSTAKA}

Zaini, Hisyam dkk. Strategi Pembelajaran Aktif. Yogyakarta : Pustaka Insan Madani, 2006

\begin{tabular}{|c|c|c|}
\hline Budiyono,Budi & Usodo & \&Yemi \\
\hline \multicolumn{3}{|c|}{ Kuswardi.2012.Model,Media } \\
\hline Evaluasi & & Pembelajaran \\
\hline PKn.Sur & & \\
\hline
\end{tabular}

Degeng, I.S. (1997). Strategi Pembelajaran: Mengorganisasi isi dengan Model Elaborasi. Malang: IKIP dan Ikatan Profesi Teknologi Pendidikan Indonesia 


\section{Jurnal Pendidikan Teknologi Informasi}

Depdiknas. 2006. Bunga Rampai Keberhasilan Guru dalam Pembelajaran (SMA, SMK, dan SLB). Jakarta: Depdiknas.

Hamzah. 201l. Teori Motivasi dan Pengukurannya: Analisis di Bidang Pendidikan. Jakarta: Bumi Aksara. http:///sunartombs.wordpress.com/2009/06/I 5/pengertian-dan-penerapan-metodejigsaw: Diakses pada tanggal 07 Maret 2012

http://carapedia.com/model_pembelajaran_jig saw_info587.html : Diakses pada tanggal 07 Maret 2012

http://infoini.com/20I/pengertian-metodejigsaw.html : Diakses pada tanggal 07 Maret 2012

Irma Pujiati . 2008 .Peningkatan Prestasiidan KetuntasanBelajar PKn Melalui Pembelajaran KooperatifTipe JIGSAW . Jurnal IImiah Kependidikan, Vol. I, No.

John W, Santrock. 2009. Psikologi Pendidikan. Jakarta: Salemba

Kanwa Publisher. Muhadi. 20II. Penelitian Tindakan Kelas. Yogyakarta: Shira Media.

Muslich, Masnur. 2009. Melaksanakan PTK itu Mudah (Classroom Action Research) Pedoman Praktis bagi Guru Profesional. Jakarta: Bumi Aksara.

Paul M La Bounty dkk . 20II . International Society of Sports Nutrition position stand: meal frequency.springer.com (20 September 2012)

Pembelajaran Kooperatif Tipe JIGSAW . 20II . http://www.sarjanaku.com ( 24 September 2012)

Prasetya, Ardhiyan. 20I2. Peningkatan Keterampilan Menulis Naskah Drama Satu Babak dengan Media Gambar Seri pada Siswa Kelas III-E SMP Negeri 2 Gamping, Sleman. Skripsi Pendidikan Bahasa dan Sastra Indonesia FBS UNY.
Reigeluth, C.M. Merril MD. 1979. Classes of Instructional Variables Educational Technology.

Rudi Susila dan Cepi Riyana. 2008. Media Pembelajaran. Bandung: Jurusan Kurikulum dan Teknologi Pendidikan Fakultas IImu Pendidikan Universitas Pendidikan Indonesia.

Rusman. (20/2). Belajar dan Pembelajaran Berbasis Komputer Mengembangkan Profesionalisme Guru Abad 2l. Bandung: ALFABETA

Rusman.20II.Model-Model Pembelajaran Mengembangkan Profesionaisme Guru.Jakarta:Rajawali Pers.

Sanjaya, Wina. 201I. Strategi Pembelajaran Berorientasi Standar Proses

Sudjana, Nana. 1989. Dasar-dasar Proses Belajar Mengajar. Bandung : Sinar Baru Algensido Offset.

Sudjana, Nana. 2010. Penilaian Hasil Proses Belajar Mengajar. (Cet. XV). Bandung: PT. Ramaja Rosdakarya.

www.kabarpendidikan.blogspot.com,www.ar minaperdana.blogspot.com,www.kmpm alang.com : Diakses pada tanggal 07 Maret 2012' 